\title{
Analysis of caesarean rate and indications of university hospitals in sub- Saharan African developing countries using Robson classification system: the case of Cocody's hospital center, Abidjan-Cote d'Ivoire
}

\author{
Védi A. Louée ${ }^{1,2}$, Eléonore A. Gbary ${ }^{2}$, Soh V. Koffi ${ }^{2}$, Abdoul K. Koffi ${ }^{3}$, Mamadou Traoré ${ }^{1}$, \\ Joachim K. Konan ${ }^{2}$, N'Drin D. Effoh ${ }^{2}$, Raphael Y. Abauleth ${ }^{2}$, Firmin Kouakou ${ }^{2}$, Serge E. Boni ${ }^{2}$ \\ ${ }^{1}$ Paris Descartes University, Sud Francilien Hospital Center (Woman-Mother-Child Pole), Paris-France \\ ${ }^{2}$ Félix Houphouet-Boigny University, Faculty of Medical Sciences (Mother and Child Department, University Hospital \\ of Cocody), Abidjan-Cote d'Ivoire \\ ${ }^{3}$ Paris Descartes University, Hospital Center of Marne-la-vallée (Woman-Mother-Child Pole ), Paris-France
}

Received: 16 April 2016

Accepted: 09 May 2016

\section{*Correspondence:}

Dr. Védi A. Loué,

E-mail: drlouevedi@yahoo.fr

Copyright: () the author(s), publisher and licensee Medip Academy. This is an open-access article distributed under the terms of the Creative Commons Attribution Non-Commercial License, which permits unrestricted non-commercial use, distribution, and reproduction in any medium, provided the original work is properly cited.

\section{ABSTRACT}

Background: According to the World Health Organization (WHO), it has become imperative to monitor caesarean rates in hospitals since these rates continue to increase; WHO recommends this monitoring by the Robson's system. The study objective was to describe caesarean rates in a level 3 maternity of developing country using this system, to identify the groups likely increase overall rate of caesarean.

Methods: A retrospective and comparative study made in Cocody University Hospital Center (Abidjan-Cote d'Ivoire) over a period of twelve years. A total of 21,067 women who delivered during this period by caesarean were included.

Results: The overall rate of caesarean during the study period was $38.7 \%$ with a significant increase from Period I to Period II ( 34.8 vs. $41.7 \% ; \mathrm{p}<0.000)$. The subgroup 2 (nulliparas, single cephalic term pregnancy, caesarean before labor) made the greatest contribution to the overall CS rate with an increase of $+5 \%(10.1$ vs. $15.1 \% ; p<0,000)$. Women with previous CS (groups $5,7,8,9,10$ ) increased the caesarean rate of $+3.4 \%$ ( 7 vs. $10.4 \%$; $p<0.000$ ). The group 6 increased it of $+2.9 \%$ ( 4.7 vs $7.6 \%$; $p<0.000)$. Caesarean indications were dominated by fetal acute distress $(24.5$ vs. $22.6 \% ; \quad p<0,000)$, then followed by fetal-pelvic disproportion $(21.8$ vs. $10.7 \%)$, severe preeclampsia/eclampsia $(13.5$ vs. $17.5 \% ; \mathrm{p}<0.000)$, scarred uterus and breech presentation.

Conclusions: Robson classification has identified the groups led to a significant increase in caesarean rates in our service and therefore has good focus our preventive actions.

Keywords: Caesarean section rate, Caesarean indications, Robson classification, Tertiary maternity, Developing country, Cote d'Ivoire

\section{INTRODUCTION}

The indications and caesarean rates have changed significantly and this trend does not seem to be complete. However, determining the ideal caesarean rate in a population is a daunting task. According to a systematic review of WHO, national caesarean rate between 10 and $15 \%$ at the population level are associated with a significant decrease in maternal, neonatal and infant mortality; beyond this threshold, no effect was observed on mortality. ${ }^{1}$ In fact, priority should not be to achieve a specific rate but a rate well justified by medical indications virtually indisputable. Thus, it becomes imperative to monitor the level of Caesarean rates in institutions taking into account the specific characteristics of each population. According to WHO since 2011, the standard classification system that would compare rates of caesarean on national and international way, useful 
and practical and thus to monitor caesarean rates in the same establishment is Robson's classification. ${ }^{2}$ The Robson's system class all pregnant women in 10 categories based on the following obstetric factors: previous obstetric history (nulliparous, multiparous with or without a previous CS); course of pregnancy (spontaneous or induced labor or planned prelabour CS); pregnancy category (singleton with cephalic, breech or other mal-presentation or multiple pregnancy); and gestational age (preterm or term).

In black Africa in general, from 1990, in reference maternities of university hospitals of major cities, the evolution of caesarean rates tend to know a real inflation like in developed countries. ${ }^{3}$ While Sub-Saharan Africa hardly bear the consequences of high and unjustified rate of scarred uterus with its corollary of morbidity and obstetric mortality. ${ }^{4}$

The study objective was to describe caesarean rates in a tertiary maternity of developing country (like Cote d'Ivoire) by presenting the case of our maternity using Robson classification, to identify the groups likely increase overall rate of caesarean lead to better preventive measures.

\section{METHODS}

We conducted a retrospective and comparative study over a period of twelve years in the University Hospital Center of Cocody (UHCC) in Abidjan-Cote d'Ivoire, from $1^{\text {st }}$ January 2004 to $31^{\text {st }}$ December 2015. During this period, 21,067 women who delivered by caesarean section (CS) were included.

In Abidjan, economic capital of our country numbering about 4 million people, there are three level III maternities including that of the UHCC. Our maternity is an example of tertiary maternity of developing countries which aim is to receive and manage all gynecological and obstetric emergencies in the northern sector of Abidjan (about 22 maternities and peripheral health centers) and surrounding towns within a radius of about 200 kilometers.

For Each woman, an epidemiological sheet was elaborated. Keys studied include women general characteristics: maternal age, mode of admission (evacuated or came themselves), the execution context of CS (urgent or not), caesarean indications and obstetric factors of Robson ten group classification. To better appreciate the evolution of the data, they were compared on arbitrary two periods of same duration (Period I: 2004-2009 and Period II: 2010-2015). We analysed proportion of deliveries, caesarean rates, CS indications; the contribution of each Robson group to the total CS rate in Period I and Period II, and the contribution of each group to the change in overall CS from Period I to Period II and to eliminate the element of chance in the variations we used as statistical test the comparison of proportions.
Statistical analysis of the variables was studied using the Chi-square test and Fisher's exact test, the result being significant for $\mathrm{p}$-values $<5 \%$.

\section{RESULTS}

Table 1: Number of births and caesarean rates over the study period.

\begin{tabular}{|c|c|c|c|c|}
\hline & $\begin{array}{l}\text { Period I } \\
2004- \\
2009\end{array}$ & $\begin{array}{l}\text { Period II } \\
2010- \\
2015\end{array}$ & Total & $\begin{array}{l}\text { p- } \\
\text { value }\end{array}$ \\
\hline $\begin{array}{l}\text { Number of } \\
\text { deliveries }\end{array}$ & 23,880 & 30,533 & 54,413 & \\
\hline Vaginally & 15,564 & 17,782 & 33,346 & \\
\hline Caesarean & 8,316 & 12,751 & 21,067 & \\
\hline $\begin{array}{l}\text { Caesarean } \\
\text { rates }(\%)\end{array}$ & $34.8 \%$ & $41.7 \%$ & & 0.000 \\
\hline
\end{tabular}

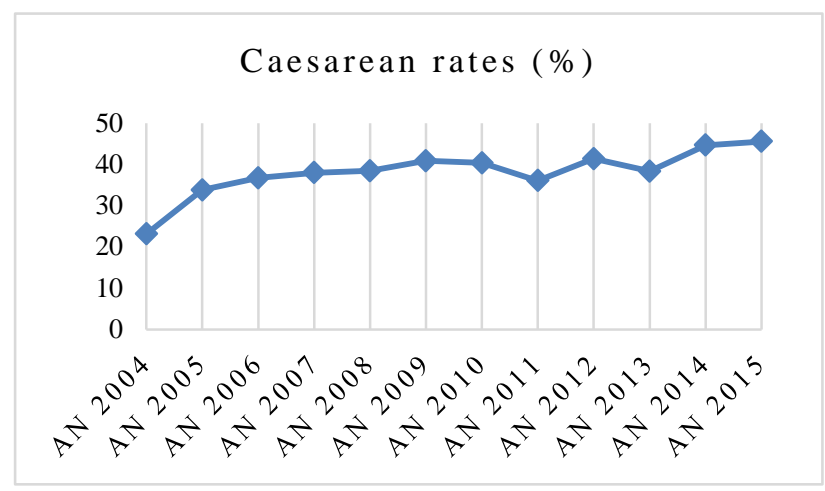

Figure 1: Evolution curve of cesarean rates in the last twelve years in our service.

\section{Proportion of deliveries, number of caesarean section and cesarean rates evolution}

During the study Period (2004-2015), over twelve consecutive years in our service, there were 54,413 births including 21,067 caesareans. The average rate of caesarean was $38.7 \%$ with a minimum of $23.1 \%$ (2004) and a maximum of $41.8 \%$ (2015).

The caesarean section rate increased from $34.8 \%$ (Period I) to $41.7 \%$ (Period II), an increase of $6.9 \%(p<0,000)$ : table 1 .

Changes in rates of caesarean section in our service presents three periods of increase (2004-2010; 2011-2012 and 2013-2015) and two down periods (2010-2011 and 2012-2013). Figure 1 reflects this evolution year by year over the twelve years.

\section{Women general characteristics}

The average age of patients was 24.6 years (minimum: 12 years; maximum: 51 years). They were admitted in our department evacuated by peripheral centers in $67.7 \%$ of 
cases. Nulliparous women represent $63.7 \%$ of total patients. Caesarean section was performed in $83.3 \%$ of cases in emergency. Caesarean indications were dominated by fetal acute distress (24.5 vs. 22.6\%; $\mathrm{p}<0,000$ ), then followed by fetal-pelvic disproportion
(21.8 vs. $10.7 \%)$, severe preeclampsia/eclampsia (13.5 vs. $17.5 \% ; \mathrm{p}<0.000)$, scarred uterus and breech presentation. Caesarean indications in our service during the study period are detailed in Table 2.

Table 2: Detailed CS indications in our service during the study period.

\begin{tabular}{|c|c|c|c|c|c|}
\hline \multirow{2}{*}{ CS indications } & \multicolumn{2}{|c|}{ Period I } & \multicolumn{2}{|c|}{ Period II } & \multirow{2}{*}{ p-value } \\
\hline & n & $\%$ & n & $\%$ & \\
\hline -Fetal pelvic disproportion & 1813 & 21.8 & 1364 & 10.7 & 0.00 \\
\hline -Covering placenta & 424 & 5.1 & 574 & 4.5 & 0.05 \\
\hline -Malpresentation & 408 & 4.9 & 255 & 2.0 & 0.00 \\
\hline - Praevia tumors & 42 & 0.5 & 127 & 1.0 & 0.00 \\
\hline -Surgical basins & 408 & 4.9 & 536 & 4.2 & 0.01 \\
\hline -Acute fetal distress & 2038 & 24.5 & 2882 & 22.6 & 0.00 \\
\hline -funicular pathology & 150 & 1.8 & 319 & 2.5 & 0.00 \\
\hline -Scarred uterus & 582 & 7.0 & 1326 & 10.4 & 0.00 \\
\hline -Breech presentation & 391 & 4.7 & 969 & 7.6 & 0.00 \\
\hline -Precious child/aged nulliparas & 50 & 0.6 & 179 & 1.4 & 0.00 \\
\hline -Macrosomia & 349 & 4.2 & 599 & 4.7 & 0.08 \\
\hline -Severe preeclampsia/eclampsia & 1123 & 13.5 & 2168 & 17.0 & 0.00 \\
\hline -Dynamic dystocia & 233 & 2.8 & 638 & 5.0 & 0.00 \\
\hline -Cervical dystocia & 175 & 2.1 & 381 & 3.0 & 0.00 \\
\hline -Pathology and pregnancy & 33 & 0.4 & 217 & 1.7 & 0.00 \\
\hline -Infections and pregnancy & 100 & 1.2 & 217 & 1.7 & 0.00 \\
\hline Total & 8316 & 100 & 12751 & 100 & \\
\hline
\end{tabular}

Table 3: Proportion of deliveries, number of CS, relative size and contribution of each Robson group to increased CS rate from Period I to Period II.

\begin{tabular}{|c|c|c|c|c|c|c|c|}
\hline \multirow{2}{*}{\multicolumn{2}{|c|}{ Robson Group Characteristics }} & \multicolumn{2}{|c|}{ Period 1} & \multicolumn{2}{|c|}{ Period 2} & \multirow{2}{*}{$\begin{array}{l}\text { Variation } \\
\%\end{array}$} & \multirow{2}{*}{$p$ value } \\
\hline & & n & $\%$ & n & $\%$ & & \\
\hline $\begin{array}{l}\text { Spontaneous labor: } 1 \text {, } \\
3\end{array}$ & $\begin{array}{l}\text { 1-Nulliparas, single cephalic term } \\
\text { pregnancy } \\
\text { 3-Multiparas, single cephalic term } \\
\text { pregnancy }\end{array}$ & $\begin{array}{l}3019 \\
1555\end{array}$ & $\begin{array}{l}36.3 \\
18.7\end{array}$ & $\begin{array}{l}4399 \\
2104\end{array}$ & $\begin{array}{l}34.5 \\
16.5\end{array}$ & $\begin{array}{l}-1.8 \\
-2.2\end{array}$ & $\begin{array}{l}0,00 \\
0,00\end{array}$ \\
\hline Total & & 4575 & 55.0 & 6503 & 51,0 & $-4,0$ & 0,00 \\
\hline Induced labor: 2, 4 & $\begin{array}{l}\text { 2-Nulliparas, single cephalic term } \\
\text { pregnancy } \\
\text { 4-Multiparas, single cephalic term } \\
\text { pregnancy }\end{array}$ & $\begin{array}{l}998 \\
383\end{array}$ & $\begin{array}{r}12,0 \\
4.6\end{array}$ & $\begin{array}{l}893 \\
384\end{array}$ & $\begin{array}{l}7,0 \\
3,0\end{array}$ & $\begin{array}{l}-5,0 \\
-1,6\end{array}$ & $\begin{array}{l}0,00 \\
0,00\end{array}$ \\
\hline Total & & 1381 & 16,6 & 1277 & 10,0 & $-6,6$ & 0,00 \\
\hline $\begin{array}{l}\text { Cesarean before } \\
\text { labor: } 2,4\end{array}$ & $\begin{array}{l}\text { 2-Nulliparas, single cephalic term } \\
\text { pregnancy } \\
\text { 4-Multiparas, single cephalic term } \\
\text { pregnancy }\end{array}$ & $\begin{array}{l}840 \\
549\end{array}$ & $\begin{array}{r}10,1 \\
6,6\end{array}$ & $\begin{array}{l}1925 \\
752\end{array}$ & $\begin{array}{r}15,1 \\
5,9\end{array}$ & $\begin{array}{r}+5,0 \\
-0,7\end{array}$ & $\begin{array}{l}0,00 \\
0,04\end{array}$ \\
\hline Total & & 1389 & 16,7 & 2677 & 21,0 & $+4,3$ & 0,00 \\
\hline $\begin{array}{l}\text { Scarred uterus: } 5,7 \text {, } \\
8,9,10\end{array}$ & $\begin{array}{l}\text { 10- Single cephalic preterm pregnancy } \\
\text { 9- Single oblique or transverse pregnancy } \\
\text { 8- Multiple pregnancy } \\
\text { 7-Multiparas, single breech pregnancy } \\
\text { 5-Multiparas, single cephalic term } \\
\text { pregnancy }\end{array}$ & $\begin{array}{l}33 \\
166 \\
50 \\
83 \\
249\end{array}$ & $\begin{array}{l}0,4 \\
2,0 \\
0,6 \\
1,0 \\
3,0\end{array}$ & $\begin{array}{l}127 \\
140 \\
153 \\
268 \\
637\end{array}$ & $\begin{array}{l}1,0 \\
1,1 \\
1,2 \\
2,1 \\
5,0\end{array}$ & $\begin{array}{r}+0,6 \\
-0,9 \\
+0,6 \\
+1,1 \\
+2,0\end{array}$ & $\begin{array}{l}0,00 \\
0,00 \\
0,00 \\
0,00 \\
0,00\end{array}$ \\
\hline Total & & 581 & 7,0 & 1325 & 10,4 & $+3,4$ & $\mathbf{0 , 0 0}$ \\
\hline Nulliparas, single bree & h pregnancy : 6 & 390 & 4,7 & 969 & 7,6 & $+2,9$ & $\mathbf{0 , 0 0}$ \\
\hline Total & & 8316 & 100 & 12751 & 100 & & \\
\hline
\end{tabular}




\section{Relative size of each Robson group in Period I and Period II, contribution of each group to the change in overall CS from Period I to Period II}

Analysis based on Robson's classification (table 3) showed that group 1 was the most women population who delivered by CS in both two periods (36.3 vs.34.5\%) followed by group 3 (18.7 vs.16.5\%); however, both groups had significantly decreased CS rates from period I to period II $(\mathrm{p}<0.000)$, table 3 .

The subgroup 2 (nulliparas, single cephalic term pregnancy, caesarean before labor) made the greatest contribution to the overall $\mathrm{CS}$ rate with an increase of $+5 \%(10.1$ vs. $15.1 \% ; \mathrm{p}<0,000)$. Women with a scarred uterus (groups $5,7,8,9,10$ ) increased of $+3.4 \%$ from Period I to Period II ( 7 vs. 10.4\%; $<<0.000$ ), dominated by group 5 which increased of $+2 \%$. The group 6 (nulliparas, single breech pregnancy) increased of $+2.9 \%$ from period I to period II (4.7 vs $7.6 \%$; $<<0.000)$.

\section{DISCUSSION}

This study initiated in our service is the first of our country that is interested in the evolution of caesarean section rates by Robson classification in our university maternities. The study noted globally, a significant increase of CS rate $(+6.9 \%)$ from Period I to Period II, so associated with vaginal delivery reduction. The analysis of the evolution curve of CS in our structure (figure 1) indicates a sudden ascention period (2004-2005) related to the closure of two other university maternities in the capital for renovation, followed by a relative stabilization until 2010 and then a decrease secondary to the political and military crisis that rocked the country in 2011 and finally a new increase just after, because of that childbirth became free in our establishment.

The average rate of CS observed in this study $(38.7 \%)$ is higher than the rates of other academic structures of the African sub-Saharian regions whose average CS rates vary between 11.3 and $25.2 \% .^{3,5,6}$ Our rate is also higher than the average rate in France (15.5-20.8\%), in Canadian $(26,9 \%)$, however, our rate of the second period $(41.7 \%)$ is comparable to those of public hospitals in Italy (43.7\%) and Greek (41.6\%). ${ }^{7-11}$ But one thing is clear, there is a considerable increase in the CS rate as well in developing countries than in developed countries.

In Cote d'Ivoire, the national rate of CS is $2.7 \%$ with a maternal mortality rate of 610 per 100,000 live births and a neonatal mortality rate of 40 per 1,000 live births, which takes us away from achieving the Millennium development goals. ${ }^{12}$ As confirmed in a study conducted in a cohort of pregnant women in six West African countries (MOMA survey) which revealed that the minimal needs for CS for maternal indications were estimated between 3.6 and 6.5 per 100 deliveries. However, it was observed a rate of $1.3 \mathrm{CS}$ per 100 deliveries. ${ }^{13}$ This fact does not exclude that the rate and caesarean indications are not effectively monitored in our teaching hospitals because in reality, in our conditions of practice, caesarean section is always an intervention at risk.

Currently, the most important analysis has been performed by Robson; each group account for a particular type of population. Group 1 is actually a low-risk population, although the rate of CS of this group decreased significantly from period I to period II of our study, there is a large population of pregnant women and represents a significant percentage of the caesarean rate. Caution should be made because this fact can lead to raise CS rate in scarred uterus groups (groups 5,7,8,9 and 10 of Robson ) which resulted in an increase in the CS rate $(+3.4 \%)$ from Period I to Period II in this study. Indeed any anomaly even minimal added on the scarred uterus sometimes systematically prefer a CS to attempt vaginal delivery. Thus considering only obstetric history, women who have previously had a caesarean section are an increasingly important determinant of overall caesarean section rate as observed in the literature. ${ }^{10,14}$

Caesarean indications in these patients in group 1 are usually dominated by the acute fetal distress, fetal-pelvic disproportion and the relevance of such indications is based on a number of means of monitoring and diagnosis that we do not always have in our hospitals. So a caesarean indication in nulliparous must be discussed, discussed again in order to make it relevant and absolute that can help save the maximum number of first Caesarean section.

Our study provides another feature when the sub group 2 (Caesarean before labor, nulliparas, single cephalic term pregnancy) which rate of caesarean has increased by 5 percent from Period I to Period II (10.1 Vs.15, 1\%, $\mathrm{p}<0.000$ ), making this group the one that increased the most over the two periods of the study. Indeed it is mostly nulliparous belatedly evacuated, after initial failure treatment (note that $67.7 \%$ of patients in this study were evacuated, with $63.7 \%$ of nulliparous) before serious complications of pregnancy toxaemia. This clearly shows the reflection of the number of pregnant young incorrectly handled in peripheral centers or not followed which do not benefit from systematic treatment of arterial hypertension of pregnancy, prevention and monitoring. Confirmed by caesarean indications rate for hypertensive disease increased significantly from Period I to Period II (13.5\% vs. 17). A necessary monitoring pregnant is required and must be both clinical, biological, ultrasound with velocimetry and fetal monitoring. The group 6 (nulliparas, single breech pregnancy) increased of $+2.9 \%$ from period I to period II (4.7 vs $7.6 \%$; $\mathrm{p}<0.000)$. Indeed systematic trend in caesarean for breech delivery was immediate, consequence of publications favorable to it so that young obstetricians today do not have a good experience of breech vaginal delivery ${ }^{15}$. The caesarean rate in group 6 also influences the rate of caesarean section in group 5. The external cephalic version and vaginal breech delivery should be encouraged after rigorous selection of patients. 


\section{CONCLUSION}

The Robson system facilitates comparative analyses of caesarean sections between hospitals/centres nationally, internationally and globally. Although the average national rate of caesarean section in Cote d'Ivoire is under that the population needs, the average rate of cesarean section in our service is high in the absence of absolute relevance in some caesarean indications still dependent on our monitoring and diagnostic means. The results of this study lead us to strictly monitor the pregnancy and birth of nulliparous (in spontaneous or induced labor or with breech presentation) for increasing vaginal delivery rate in this group and therefore decrease the rate of women with previous caesarean. Decrease CS rate is possible in our service through a daily discussion of obstetric records in individual cases, a more open acceptance vaginal attempt and ongoing evaluation of practices.

Funding: No funding sources

Conflict of interest: None declared

Ethical approval: The study was approved by the Institutional Ethics Committee

\section{REFERENCES}

1. Betran AP, Torloni MR, zhang J, Ye J, Mikolajczyk $\mathrm{R}$, Deneux-Tharaux C, et al. What is the optimal rate of caesarean section at population level? A systematic review of ecologic studies. Reprod Health. 2015;12(1):57.

2. Torloni MR, Betran AP, Souza JP, Widmer M, Allen T, Gulmezoglu M, et al. Classification for caesarean section: a systematic review. PloS ONE. 2011;6(1):e14566.

3. Cissé CT, N'Gon PM, Guissé A, Faye EO, Mareau JC. Reflexions sur l'évolution des taux de césarienne en milieu africain: exemple du CHU de Dakar entre 1992 et 2001. Gynécol Obstét Fertil. 2004;32:210-7.

4. Loué VA, Dia JML, Effoh ND, Adjoby CR, Konan $\mathrm{K}$ J, Gbary AE, et al. Management and prognosis of uterine rupture during labor in an under-medicalized country: about 513 cases collected at the Cocody University Hospital Center (Abidjan-Cote d'Ivoire). Int J Reprod Contracept Obstet Gynecol. 2015;4(5):1277-82 .

5. Daniel CN, Singh S. Caesarean delivery: An experience from a tertiary institution in north western Nigeria. Niger J Clin Pract. 2016;19(1):18-24.
6. Some Der A, Ouattara S, Barro D, Traoré A, Bamabara M, Dao B. Audit des césariennes en milieu africain. Rwanda Medical Journal. 2010;68(4):32-7.

7. Lembrouck C, Mottet N, Bourtembourg A, Ramanah R, Riethmuller D. Peut-on diminuer le taux de césarienne dans un CHU de niveau III ? J Gynecol Obstet Biol Reprod (Paris). In Press, Corrected Proof, Available online 1 October 2015. 2015 Sep 30. pii: S0368-2315(15)00207-0.

8. Le Ray C, Prunet C, Deneux-Tharaux C, Goffinet F, Blondel B. Classification de Robson : un outil d'évaluation des pratiques de césarienne en France. J Gynecol Obstet Biol Reprod (Paris). 2015;44(7):60513.

9. Kelly S, Sprague A, Fell DB, Murphy P, Aelick N, Guo Y, et al. Examining Caesarean Section Rates in Canada Using the Robson Classification System. J Obstet Gynaecol Can. 2013;35(3):206-14.

10. Triunfo S, Ferrazzani S, Lanzonne A, Scambia G. Identification of obstetric targets for reducing cesarean section rate using the Robson Ten Group Classification in a tertiary level hospital. Eur J Obstet Gynecol Reprod Biol. 2015;189:91-5.

11. Mossialos E, Allin S, Karras K, Davaki K. An investigation of Caesarean sections in three Greek hospitals: the impact of financial incentives and convenience. Eur J Public Health. 2005;15:288-95.

12. UNICEF. Cote d'Ivoire, statistiques. www.unicef.org/french/infobycountry/cotedivoire_st atistics.htm. consulté le 16 Avril 2016.

13. Dumont A, De Bernis L, Bouvier-Colle M.-H, Bréart G. Santé maternelle en Afrique francophone Estimation du taux attendu de césariennes pour indications maternelles dans une population de femmes enceintes d'Afrique de l'Ouest (enquête MOMA). J Gynécol Obstét Biol Reprod. 2002;31(1):107-12.

14. Vogel JP, Betran AP, Vindevoghel N, Souza JP, Torloni MR, Zhang J, et al. Use of the robson classification to assess caesarean section trends in 21 countries: a secondary analysis of two WHO multicountry surveys. Lancet Glob Health. 2015;3(5):e260-70.

15. Loué V, Effoh N, Konan J, Gbary E, Allah C, Kassé $\mathrm{R}$, et al. Vaginal breech delivery: survey of obstetricians in specialization in Cote d'Ivoire. Int J Reprod Contracept Obstet Gynecol. 2016;5:651-5.

Cite this article as: Loué VA, Gbary EA, Koffi SV, Koffi AK, Traoré M, Konan JK, et al. Analysis of caesarean rate and indications of university hospitals in sub-Saharan African developing countries using Robson classification system: the case of Cocody's hospital center, Abidjan-Cote d'Ivoire. Int J Reprod Contracept Obstet Gynecol 2016;5:1773-7. 